\title{
Uterine endothelial cell proliferation before and after embryo implantation in rats
}

\author{
A. M. Goodger (Macpherson) and P. A. W. Rogers \\ Monash University Department of Obstetrics and Gynaecology, Monash Medical Centre, \\ 246 Clayton Rd, Clayton, Victoria, 3168, Australia
}

\begin{abstract}
Angiogenesis occurs rarely in normal adult tissues. The female reproductive tract, however, provides several exceptions, including the endometrium during early pregnancy. The aim of this study was to quantify endothelial cell proliferation (a component of angiogenesis) in the rat endometrium at about the time of implantation, using immunohistochemistry with a double staining technique. Proliferating cells were stained using an antibody against proliferating cell nuclear antigen (PCNA; clone PC10), and endothelial cells were stained with a lectin from Griffonia simplicifolia. Results showed that the endothelial cell proliferative index in the endometrium rose significantly from approximately $1 \%$ on the first 2 days of pregnancy to $13 \%$ on day 3 ; and continued to rise to $28 \%$ on day 5 . After embryo implantation, the endometrial endothelial cell proliferative index rose further to $71 \%$ on day 7 at embryo sites only; but significantly decreased to basal values at intersites. The endothelial cell proliferative indices in the myometrium and mesometrial triangle remained at basal values during the first 5 days, but increased to approximately $22 \%$ at embryo sites only by day 7 . We conclude that in the rat: (1) endometrial angiogenesis may be occurring before embryo implantation; (2) endometrial endothelial and stromal cell proliferation occurs concomitantly, except on day 3 when endothelial cell proliferation begins in advance of other stromal cell proliferation; and (3) there are two separate mechanisms controlling uterine endothelial cell proliferation during early pregnancy. The first mechanism is maternally controlled and is apparent throughout the entire endometrium from day 3; and the second mechanism is apparent after implantation in the vicinity of the embryo.
\end{abstract}

\section{Introduction}

Angiogenesis, or new blood vessel growth, is an essential process for normal developmental growth and wound healing, and plays an important role in the growth and maintenance of many solid tumours and other diseases such as diabetic retinopathy and atherosclerosis (Paweletz and Knierim, 1989; Bouck, 1990). Controlled, nonpathological angiogenesis occurs rarely in adult tissues; however, exceptions are found in the female reproductive tract. These include the ovary during folliculogenesis and formation of the corpus luteum (Bassett, 1943); and the endometrium of primates during the menstrual cycle (Ramsey, 1977), and following implantation before (Krehbiel, 1937; Welsh and Enders, 1991) and during placentation in pregnancy. The early stages of angiogenesis are characterized by endothelial cell protease production (e.g. type IV collagenase and plasminogen activator) for degradation of basement membrane and extracellular matrix, endothelial cell migration and endothelial cell division or proliferation (Zetter, 1988).

Earlier work in our laboratory involved the use of an in vitro endothelial cell migration assay (Folkman et al., 1989) with cultured endometrial explants, taken from day 3 to day 7 pregnant rats. The results showed that a significant migratory

Received 30 November 1992. response of endothelial cells towards the explants occurred only with explants from day 5 pregnant rats (Abberton and Rogers, in press) at a time approximately $4-5 \mathrm{~h}$ before the earliest detectable signs of embryo implantation (Rogers et al., 1992). This work led us to believe that angiogenesis may be occurring in the endometrium of rats at about the time of embryo implantation. The aim of the present study was to test the hypothesis that the endothelial cell migratory signal seen in vitro on day 5 of pregnancy in the rat endometrium is accompanied by endothelial cell proliferation in vivo.

\section{Materials and Methods}

\section{Experimental procedure}

Sprague-Dawley rats (female, outbred, aged 3-6 months) used in this study were housed under standard conditions ( $14 \mathrm{~h}$ light: $10 \mathrm{~h}$ dark; lights on 06:00 h). Rats from days 1-7 of pregnancy ( $n=4$ rats per day; day I taken as the day on which spermatozoa were present in the vaginal smear) were killed by $\mathrm{CO}_{2}$ asphyxiation, between 12:00-13:00 h. The uterus from each rat was perfusion fixed with $10 \%$ buffered formalin, $\mathrm{pH} 7.5$ after a $0.9 \% \mathrm{NaCl}$ washout via a cannula in the descending aorta. The uterus was excised, cut into approximately $4 \mathrm{~mm}$ Down loaded from Bioscientifica.com at 04/26/2023 06:16:03AM
via free access 
blocks and immersion fixed for $4-5 \mathrm{~h}$ under constant rotation at room temperature. On days 6 and 7 of pregnancy, embryo sites and sites between embryos (intersites) were identified. On day 6 , embryo sites were not sufficiently enlarged to allow definite positive identification. Before killing and perfusion, day 6 rats were therefore anaesthetized with Avertin $(30 \mathrm{mg}$ per $100 \mathrm{~g}$ body weight i.p. (stock solution: $5 \mathrm{~g}$ 2,2,2-tribromoethanol (Merck, Schuchardt) plus $5 \mathrm{ml}$ butan-2-ol (BDH Chemicals, Poole, Dorset); working solution: $0.25 \mathrm{ml}$ stock plus $10 \mathrm{ml}$ $0.9 \% \mathrm{w} / \mathrm{v} \mathrm{NaCl}$ ), and injected i.v. with $1 \mathrm{ml}$ of $2 \%$ Evans blue which was allowed to circulate for $15 \mathrm{~min}$. Embryo sites were identified as blue bands where leakage of the dye from the vasculature into the extracellular space had occurred. On day 7 , embryo sites were easily identified by their enlarged size. The blocks were processed overnight through increasing concentrations of ethanol, to Safsolvent (Ajax Chemicals, Auburn, NSW), then wax (Paraplast X-TRA; Oxford Labware, St Louis, MO). Four blocks were used from each animal, or eight in the case of day 6-7 rats. Transverse $5 \mu \mathrm{m}$ sections were cut and transferred to slides coated with $0.5 \%$ aminotriethoxysilane (Sigma) in ethanol. One section from each block was stained immunohistochemically for proliferating endothelial cells; and another section, within $20 \mu \mathrm{m}$ of the previously stained section, stained for all endothelial cells. Sections from embryo sites were used only if a decidual zone was present. (Overall, $75 \%$ of sections from embryo sites quantified, also contained embryo.)

\section{Immunohistochemistry}

Proliferating endothelial cells were identified using a streptavidin-biotin method of immunohistochemistry and incorporated a double staining technique. Reagents used, except where stated otherwise, were from a Histostain-DS Kit (Zymed Laboratories Inc., San Francisco, CA). Sections were dewaxed, rehydrated, and washed in 0.01 mol phosphate-buffered saline $\mathrm{I}^{-1}$ (PBS), pH 7.4 for $10 \mathrm{~min}$. Endogenous peroxidase activity was quenched with $3 \% \mathrm{H}_{2} \mathrm{O}_{2}$ in methanol $(10 \mathrm{~min})$. All proliferating cells were stained to give red nuclei using mouse-anti-ratPCNA (clone PC10; Novocastra Laboratories, Newcastle-uponTyne), a monoclonal antibody against proliferating cell nuclear antigen. PCNA is a nuclear $36 \mathrm{kDa}$ protein, the expression of which increases during the late GI phase of cycling cells and peaks during the S phase (Danova et al., 1990) and is an accessory protein for DNA polymerase delta (Bravo et al., 1987). The antibody was diluted 1:50 in 1\% BSA in PBS and incubated for $60 \mathrm{~min}$ at $37^{\circ} \mathrm{C}$, followed by biotinylated anti-mouse immunoglobulin (Ig), streptavidin-horseradish peroxidase conjugate, and 3-amino 9-ethylcarbazole (AEC) chromogen. Endothelial cells were stained using a biotinylated lectin BS- 1 from Griffonia (Bandeiraea) simplicifolia (Sigma Chemical Co, St Louis, MO). This lectin binds selectively to the sugars $\alpha$-methyl-Dgalactopyranosyl and $\mathrm{N}$-acetylgalactosamine, and has been used previously as an endothelial cell marker in mice and rats (Laitinen, 1987; Hansen-Smith et al., 1988). It was used at $50 \mu \mathrm{g}$ $\mathrm{ml}^{-1}$ in $1 \% \mathrm{BSA}$ in PBS, incubated $30 \mathrm{~min}$ at room temperature, after a 10 min trypsin (Sigma) digestion at $37^{\circ} \mathrm{C}(0.1 \%$ in $0.1 \%$ $\mathrm{CaCl}_{2}, \mathrm{pH} 7.8$ ), and followed by streptavidin-alkaline phosphatase conjugate, and AP-Blue. Negative controls using $10 \mu \mathrm{g}$ mouse IgG2a ml ${ }^{-1}$ (Chemicon International Inc., Temecula, $\mathrm{CA}$ ) in $1 \%$ BSA in PBS instead of the PCNA antibody, and

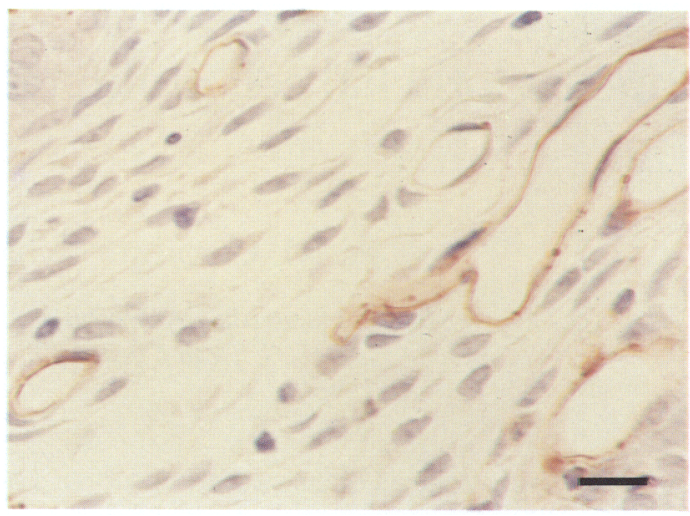

Fig. 1. Photomicrograph of rat endometrium, stained with the lectin from Griffonia simplicifolia and 3-amino 9-ethylcarbazole (AEC) chromogen (red), and haematoxylin (blue), for a total endothelial cell nuclei count. Oil immersion. Bar $=10 \mu \mathrm{m}$.

0.01 mol methyl $\alpha$-D-galactopyranoside $\mathrm{I}^{-1}$ (Sigma) mixed with the lectin (Hansen-Smith et al., 1988) were also carried out.

Separate sections were stained for estimates of total numbers of endothelial cell nuclei using the lectin at $25 \mu \mathrm{g} \mathrm{ml}^{-1}$ with the AEC chromogen (red), and haematoxylin which stains all cell nuclei blue (Fig. 1).

\section{Quantification}

Quantification of stained sections was performed using a $\times 40$ objective lens and microscope (BH-2, Olympus Optical Co., Tokyo) linked via a colour CCD video camera (MW-F15E, Panasonic; Matsushita Communication Industrial Co.) to a personal computer (Commodore Amiga 2000, Lane Cove, NSW) with stereology software (Grid, Graffiti Data, Medico Soft Div., Silkeborg). Counts of cell nuclei were made from the computer screen by the operator. Numbers of proliferating endothelial cell nuclei $\mathrm{mm}^{-2}$ were estimated in the endometrium, myometrium and mesometrial triangle by counting the whole section. The total number of endothelial cell nuclei $\mathrm{mm}^{-2}$ were estimated in each region by sampling approximately $10 \%$ of each section, using a motorized stage and apparatus to advance the stage at set intervals (MS 316, Lang GMBH and $\mathrm{Co}$, Hüttenberg). From this information, an index of endothelial cell proliferation was derived, i.e. the number of proliferating endothelial cells/the total number of endothelial cells, expressed as a percentage.

\section{Results}

The pattern of overall cell proliferation seen in the endometrium with the PCNA antibody varied with the day of pregnancy (Fig. 2), and confirmed the pattern of mitoses seen by earlier workers in the endometrium of rats (Chaudhury and Sethi, 1970) and mice (Finn and Martin, 1967; Finn and Porter, 1975). In addition, this pattern was consistent within uteri and between rats on the same day of pregnancy. On day 1 of pregnancy, there was a moderate degree of proliferative activity (as 


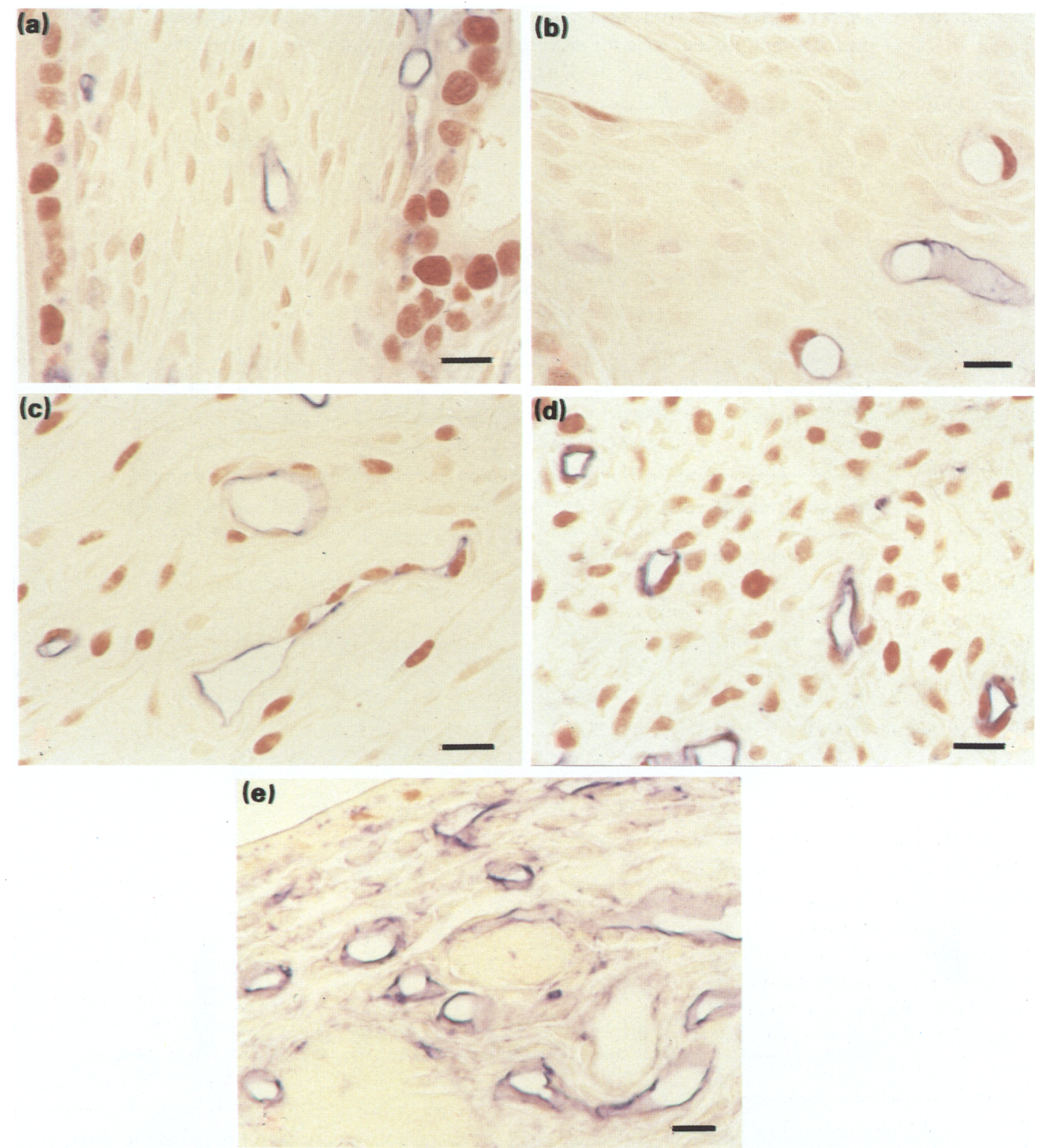

Fig. 2. Photomicrographs of rat endometrium, stained with the proliferating cell nuclear antigen (PCNA) antibody and 3-amino 9-ethylcarbazole (AEC) chromogen (red), and lectin with AP-Blue chromogen. (a) Day 2 of pregnancy. Luminal and glandular endothelial cells only show evidence of proliferative activity - i.e. are stained with dark, red nuclei. Endothelium is stained blue. Oil immersion. (b) Day 3 of pregnancy. Some endothelial cell nuclei are undergoing proliferation; other stromal cell nuclei are not stained. Oil immersion. (c) Day 5 of pregnancy. Proliferating endothelial cell and other stromal cell nuclei are apparent. Oil immersion. (d) Day 7 of pregnancy at embryo site. Numerous proliferating endothelial cell and other stromal cell nuclei are apparent. Oil immersion. (e) Day 7 of pregnancy at intersite from the same animal as in (d). There is very little proliferative activity. Bars $=10 \mu \mathrm{m}$.

defined by the presence of red nuclei) in the luminal epithelium, and very little proliferative activity in the glandular epithelium, endometrial stroma, myometrium and mesometrial triangle. On day 2 of pregnancy, there was a high degree of proliferative activity in the luminal and glandular epithelium (approaching $100 \%$ in the glandular epithelium), and virtually none elsewhere. On day 3 , the degree of proliferative activity in the epithelium declined substantially, but increased in the endometrial stroma. In this compartment, the vast majority of proliferating cells were endothelial cells. There was again virtually no proliferative activity in the myometrium or mesometrial triangle. On day 4 , proliferative activity was minimal in the epithelium, but was increased throughout the stroma generally (i.e. in endothelial cells and other stromal cells), with no change in the myometrium or mesometrial triangle. The pattern in the endometrium on day 5 , and days 6 and 7 of pregnancy at embryo sites, was similar to that seen on day 4 , although more proliferating cells were seen in the stroma. Many cells in the decidual zone on days 6 and 7 at embryo sites were proliferating. In contrast, at intersites on days 6 and 7 in the endometrium, 
Table 1. Numbers of proliferating (proliferating cell nuclear antigen positive) endothelial cells for each region of the rat uterus in a transverse section

\begin{tabular}{lrrrr}
\hline Day of pregnancy & Endometrium & Myometrium & $\begin{array}{c}\text { Mesometrial } \\
\text { triangle }\end{array}$ \\
\hline 1 & $6.50 \pm 1.68$ & $6.31 \pm 1.70$ & $2.25 \pm 0.42$ \\
2 & $5.00 \pm 1.40$ & $1.88 \pm 0.80$ & $1.38 \pm 0.64$ \\
3 & $77.81 \pm 5.56$ & $1.81 \pm 0.61$ & $1.31 \pm 0.34$ \\
4 & $111.25 \pm 10.44$ & $2.94 \pm 0.77$ & $1.13 \pm 0.46$ \\
5 & $183.31 \pm 16.85$ & $4.38 \pm 1.00$ & $3.88 \pm 1.63$ \\
6 Embryo site & $275.25 \pm 15.29$ & $19.13 \pm 3.38$ & $16.19 \pm 2.26$ \\
6 Intersite & $27.75 \pm 7.00$ & $3.38 \pm 1.43$ & $3.50 \pm 1.58$ \\
7 Embryo site & $887.07 \pm 39.67$ & $57.93 \pm 10.28$ & $55.53 \pm 6.66$ \\
7 Intersite & $0.81 \pm 0.29$ & $1.81 \pm 0.81$ & $2.88 \pm 1.22$ \\
\hline
\end{tabular}

*This group contains one animal in which three embryo sites were quantified, not four. Values are means \pm SEM; $n=4$ rats per day of pregnancy, with four different sections at least $4 \mathrm{~mm}$ apart quantified per animal.

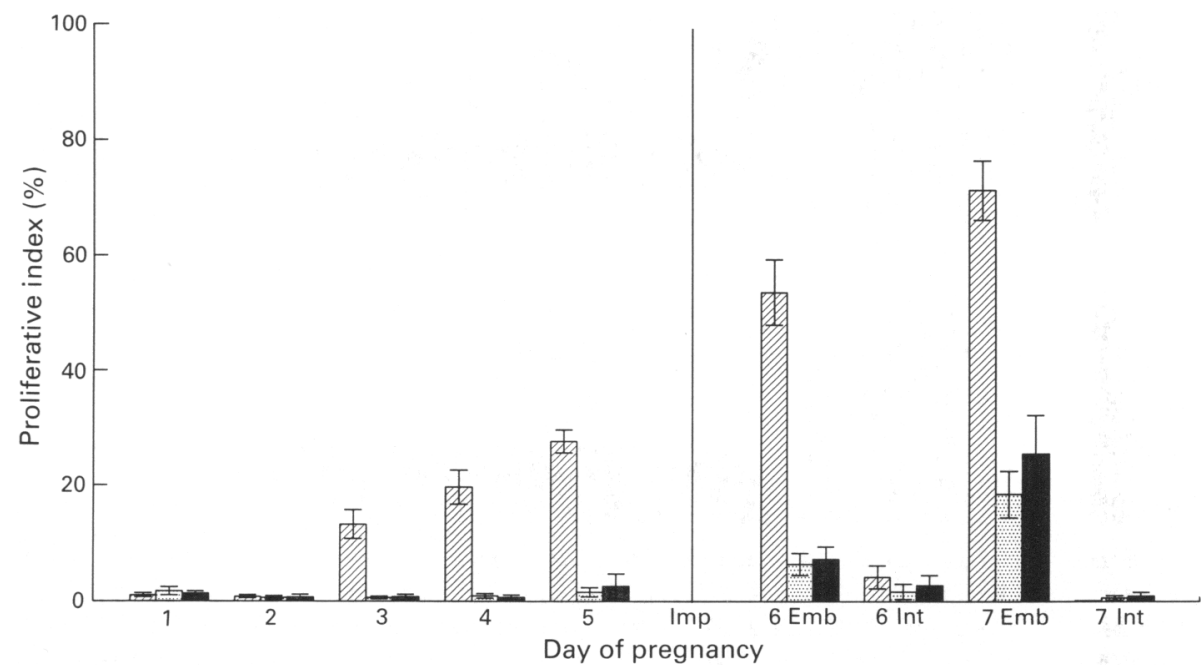

Fig. 3. Rat endothelial cell proliferative indices (\%; mean \pm SEM) versus day of pregnancy in the endometrium ( $囚)$, myometrium $($ ), and mesometrial triangle $(\square)$. The line at Imp (implantation) indicates the approximate time of embryo implantation. Emb: embryo site; Int: intersite.

there was little proliferative activity in the stroma; again there was little proliferative activity in the glandular epithelium, but some was evident in the luminal epithelium at day 7 intersites. Similarly, proliferative activity in the myometrium and mesometrial triangle began to increase on days 6 and 7 at embryo sites, although at intersites, the degree of proliferative activity remained low.

The mean numbers of proliferating (PCNA-positive) endothelial cells in the endometrium, myometrium and mesometrial triangle in each transverse section quantified from each rat, are shown (Table 1). The endothelial cell proliferative indices throughout the uterus varied with the day of pregnancy and the results of the means \pm SEM versus day of pregnancy are shown (Fig. 3 and Table 2). The results from each of the nine groups in the endometrium, myometrium, and mesometrial triangle were analysed by ANOVA; the degrees of freedom in each case were
8,27 ; and the respective $F$ values were $71.83,13.32$, and 9.94 , with $P<0.0001$ for each region of the uterus. The levels of significance between the various groups within each region are also shown in Table 2.

\section{Discussion}

We showed, by using immunohistochemistry with an antibody against PCNA and a lectin as a marker for endothelium, that the endothelial cell proliferative index in the endometrium of rats increases significantly from $1.04 \pm 0.38-0.8 \pm 0.28 \%$ on days $1-2$ of pregnancy, to $13.31 \pm 2.54 \%$ on day 3 of pregnancy. The endothelial cell proliferative index continued to rise throughout the entire endometrium on days 4 and 5 of pregnancy, to $27.68 \pm 1.96 \%$; and on days 6 and 7 at embryo 
Table 2. Rat endothelial cell proliferative indices (number of proliferating endothelial cells $\mathrm{mm}^{-2}$ divided by the total number of endothelial cells $\mathrm{mm}^{-2}$, expressed as a percentage

\begin{tabular}{lccc}
\hline Day of pregnancy & Endometrium & Myometrium & $\begin{array}{c}\text { Mesometrial } \\
\text { triangle }\end{array}$ \\
\hline 1 & $1.04 \pm 0.38$ & $1.76 \pm 0.73$ & $1.31 \pm 0.44$ \\
2 & $0.80 \pm 0.28$ & $0.61 \pm 0.34$ & $0.74 \pm 0.44$ \\
3 & $13.31 \pm 2.54^{\mathrm{a}}$ & $0.63 \pm 0.25$ & $0.77 \pm 0.45$ \\
4 & $19.71 \pm 2.97^{\mathrm{b}}$ & $0.93 \pm 0.39$ & $0.71 \pm 0.38$ \\
5 & $27.68 \pm 1.96^{\mathrm{b}, \mathrm{c}}$ & $1.57 \pm 0.79$ & $2.64 \pm 2.16$ \\
6 Embryo site & $53.59 \pm 5.66^{\mathrm{b}, \mathrm{d}}$ & $6.43 \pm 1.93^{\mathrm{i}}$ & $7.32 \pm 2.17$ \\
6 Intersite & $4.21 \pm 1.99^{\mathrm{e} . \mathrm{f}}$ & $1.68 \pm 1.30$ & $2.76 \pm 1.78$ \\
7 Embryo site & $71.27 \pm 5.13^{\mathrm{g}}$ & $18.49 \pm 4.01^{\mathrm{j}}$ & $25.51 \pm 6.72^{\mathrm{k}}$ \\
7 Intersite & $0.11 \pm 0.06^{\mathrm{ch}}$ & $0.61 \pm 0.41$ & $0.91 \pm 0.67$ \\
\hline
\end{tabular}

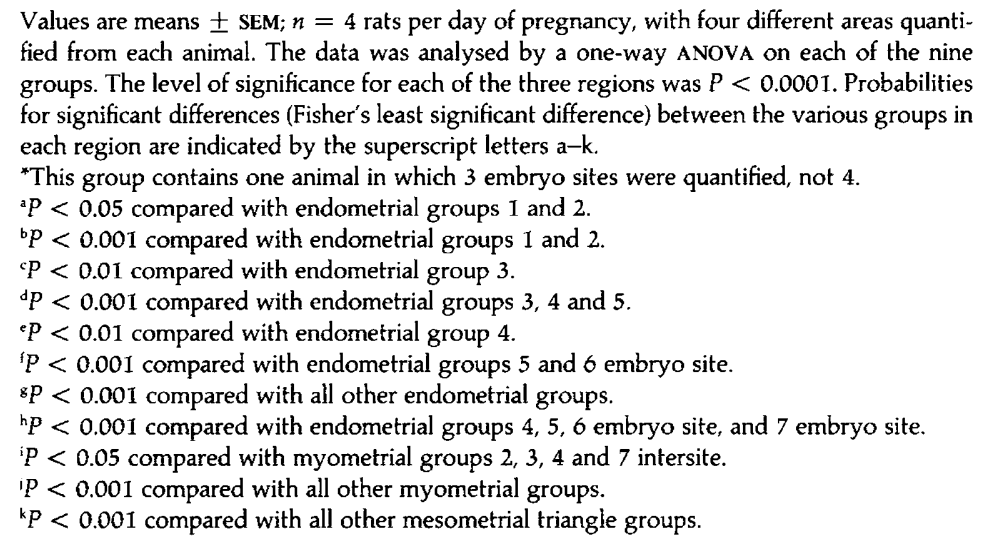

sites only, to $71.27 \pm 5.13 \%$. At intersites on days 6 and 7 , the endothelial cell proliferative index fell sharply towards the values found before day 3 . In the myometrium and mesometrial triangle, the endothelial cell proliferative index did not change significantly during the first 5-6 days of pregnancy; but did rise significantly on day 7, at embryo sites only. (This probably reflects the increased uterine growth at embryo sites.)

The endothelial cell proliferative indices seen on days $I$ and 2 of pregnancy were similar to the rather low $\left[{ }^{3} \mathrm{H}\right]$ thymidine labelling indices of between 0 and $2.5 \%$ reported for endothelial cells in other adult tissues (e.g. $0.01 \%$ in the retina and $0.14 \%$ in the myocardium of rats, Engerman et al., 1967; 2.5\% for the vessels surrounding active hair follicles of the rat, Sholley and Cotran, 1976;0.4\% in the liver and kidney and $2.4 \%$ in the Haversian canals and other capillaries of the femur in 8-12 week-old-mice, Tannock and Hayashi, 1972). These low levels of endothelial cell proliferative activity presumably represent basal values.

Between days 3 and 5 before implantation (the earliest detectable sign of which is an increase in vascular permeability in the vicinity of the embryo, at approximately $17: 00 \mathrm{~h}$ on day 5 in our rats; Rogers et al., 1992) the endothelial cell proliferative indices seen were similar to endothelial cell $\left[{ }^{3} \mathrm{H}\right]$ thymidine labelling indices reported for other situations in which endothelial cell division is occurring, for example $23 \%$ in the chick chorioallantoic membrane (CAM) on day 11 of incubation
(Ausprunk et al., 1974). Endothelial cells in other female reproductive tissues have also exhibited thymidine labelling indices equal to or greater than those observed for tumour endothelial cells (Reynolds et al., 1992), for example $25.6 \%$ in early developing corpora lutea $7-8 \mathrm{~h}$ after ovulation in rats (Gaede et al., 1985). The large endothelial cell proliferative indices at embryo sites after implantation (up to $72 \%$ ) are substantially higher than thymidine labelling indices reported for other tissues. The increased endometrial endothelial cell proliferative indices seen before and after implantation probably reflect the fact that the endometrium is unusual in that it undergoes substantial and rapid growth and remodelling in preparation for, and during pregnancy. Another relevant comparison here can be made between the epithelium lining the duodenal mucosa, which is regarded as having a high turnover rate, and had a thymidine labelling index of $14 \%$ (Messier and Leblond, 1960) and the endometrial luminal epithelium of the mouse treated with a single injection of $50 \mathrm{ng}$ oestradiol after ovariectomy, which had a thymidine labelling index of $71 \%$ (Martin et al., 1973). It must also be borne in mind that PCNA is not a definitive Sphase marker, as thymidine (and bromodeoxyuridine) incorporation is. Its synthesis begins during the late G1 phase of cycling cells, since it is required for leading strand synthesis during DNA replication (Fairman, 1990). Higher than expected PCNApositive fractions have been found in some tumours, and it has been suggested that this could be due to the long half-life of PCNA (which varies among different cell types; Baserga, 1991) 
compared to the short cell cycle time (Wijsman et al., 1992). In normal rat small intestine, PCNA immunoreactivity persisted for only a short time (estimated at $9 \mathrm{~h}$ ) in epithelial cells that had stopped DNA replication when moving from the crypt towards the villus (Wijsman et al., 1992). However, normal non-cycling cells and tissues synthesize very little or no PCNA (Celis et al., 1984), and the distribution of PCNA immunoreactivity in normal tissues was found to correspond to those cells known to be cycling (Hall et al., 1990).

The pattern of mitoses seen by previous workers in the endometrium of colchicine-treated rats (Chaudhury and Sethi, 1970) and mice (Finn and Martin, 1967; Finn and Porter, 1975) is similar to the overall pattern of cellular proliferation seen by PCNA staining in this study, and therefore tends to validate this newer technique. The presence of PCNA-positive decidual cells on days 6 and 7 is in agreement with the observations of mitotic figures within and at the periphery of the decidual cup by the afternoon of day 6 in the rat by Enders and Schlafke (1967), but not with Finn and Martin (1967) who state that "... the stromal cells immediately around the [mouse] blastocyst differentiate into decidual cells and cease to divide, while active division continues outside the decidualized area". As many decidual cells become binucleate (Krehbiel, 1937), this could be due to DNA synthesis without subsequent mitosis, or to a species difference between the rat and mouse, or to the large variability between different implantation sites at the same time owing to the rapidly occurring changes.

In terms of the original hypothesis, it does seem that the endothelial cell migratory signal seen in vitro on day 5 before implantation is accompanied by endothelial cell proliferation in vivo. However, after implantation, endothelial cell proliferation continues at embryo sites, and this contrasts with the lack of endothelial cell migratory signal production in vitro. The endothelial cell migratory activity together with the endothelial cell proliferative activity on days $3-5$ provides strong evidence that angiogenesis may be occurring in the rat endometrium before embryo implantation. It also suggests that endothelial cell proliferation may commence before endothelial cell migration in this situation; a significant increase in endothelial cell proliferation occurred on day 3, compared with day 5 for the significant increase in endothelial cell migratory signal production (Abberton and Rogers, in press). This situation is in contrast to the usual order of events quoted for angiogenesis in which endothelial cell proliferation occurs after sprout formation by endothelial cell migration (Folkman, 1985), or endothelial cell proliferation occurs concomitantly with sprout formation by endothelial cell migration (Presta and Rifkin, 1988). It should be noted, however, that these conclusions have been drawn mainly from observations made in experimental systems, for example in the CAM assay, or for tumour angiogenesis, and not in physiological, non-pathological situations. The lack of endothelial cell migratory signal production from day 6 and 7 embryo sites in vitro may indicate that endothelial cell migration, and therefore angiogenesis as such, may not be occurring in vivo, or that the in vitro system was lacking a factor(s) necessary for eliciting a response, for example lack of embryo, or lack of decidual cells.

The results indicate that there are two separate mechanisms controlling the proliferation of endothelial cells in the endo- metrium at about the time of implantation. The first mechanism is maternally controlled and is apparent from days 3 to 5 of pregnancy throughout the entire endometrium before embryo implantation. The second mechanism is an embryo mediated signal acting locally after implantation on days 6 and 7. It seems probable that the first signal is triggered by progesterone. Abberton and Rogers (in press) also showed that endometrial explants from ovariectomized rats treated with progesterone for $48-72 \mathrm{~h}$ elicited a significant migratory response from cultured bovine endothelial cells. In rats, progesterone concentrations begin to increase from day 3 of pregnancy (Forcelledo et al., 1981), and progesterone is known to result in a switch from endometrial epithelial cell proliferation under oestrogen influence, to stromal cell proliferation in mice (Finn and Martin, 1967; Martin and Finn, 1968) and rats (Clark, 1971). Progesterone itself is not mitogenic for endothelial cells (Johannisson, 1986), and must therefore be acting via a secondary signal. The embryo-mediated signal acting after implantation may originate directly from the embryo, or may result from the decidual zone. Alternatively the endothelial cell and stromal cell proliferation that occurs at embryo sites after implantation may simply be a continuation of the original signal before implantation, with a switching off or deactivation of cell proliferation in the absence of an embryo or decidual cells at intersites.

It is interesting to speculate about the nature and identity of the signal(s) responsible for the endothelial cell proliferation in the endometrium before and after embryo implantation. Endothelial cell proliferation, and other stromal cell proliferation (although not quantified) occur concomitantly, except on day 3 when endothelial cell proliferation has commenced in advance of other stromal cell proliferation. The signal responsible for the endothelial cell proliferation may or may not be the same as the signal for non-endothelial stromal cell proliferation. Alternatively, one of the less specific angiogenic factors may be responsible from day 3 with the endothelial cells being the first cells to respond. Several factors that are known to be involved in the process of angiogenesis have been located (or at least implicated) in the uterus, and any combination of them could be responsible for the endothelial cell proliferation before and after implantation. They include fibroblast growth factor (FGF), (Carlone and Rider, 1992; Cullinan and Koos, 1991), endothelial cell stimulating angiogenesis factor (ESAF; Taylor et al., 1992), vascular endothelial cell growth factor (VEGF; Cullinan and Koos, 1991), and hyaluronic acid fragments (Ashworth et al., 1990). Hypoxia is also known to result in angiogenesis, for example in retinopathy of prematurity (Gole et al., 1982), and it is possible that reduced oxygen tension (as a result of the increased vascular permeability and oedema at embryo sites) may play a role in new blood vessel growth and endothelial cell proliferation during embryo implantation. The factor(s) responsible may of course not be any of the currently known angiogenic factors; or a reduction of growth inhibitors may be involved.

The authors thank N. Wreford from the Institute for Reproduction and Development, Monash University, for advice and use of his equipment for quantification; and the National Health and Medical Research Council for funding support. 


\section{References}

Abberton KM and Rogers PAW Production of an endothelial cell migratory signal in rat endometrium during early pregnancy Biology of Reproduction (in press)

Ashworth CJ, Fliss MFV and Bazer FW (1990) Evidence for steroid control of a putative angiogenic factor in the porcine uterus Journal of Endocrinology 125 15-19

Ausprunk DH, Knighton DR and Folkman J (1974) Differentiation of vascular endothelium in the chick chorioallantois: a structural and autoradiographic study Developmental Biology 38 237-248

Baserga $\mathbf{R}$ (1991) Growth regulation of the PCNA gene Journal of Cell Science 98 433-436

Bassett DL (1943) The changes in the vascular pattern of the ovary of the albino rat during the estrous cycle American Joumal of Anatomy 73 251-291

Bouck N (1990) Tumor angiogenesis: the role of oncogenes and tumor suppressor genes Cancer Cells 2 179-185

Bravo R, Frank R, Blundell PA and Macdonald-Bravo H (1987) Cyclin/PCNA is the auxiliary protein of DNA polymerase- $\delta$ Nature $326515-517$

Carlone DL and Rider V (1992) Immunocytochemical localization of bFGF during uterine remodelling in the pregnant rat Biology of Reproduction 46 (Supplement 1), 177

Celis JE, Bravo R, Larsen PM and Fey SJ (1984) Cyclin: a nuclear protein whose level correlates directly with the proliferative state of normal as well as transformed cells Leukemia Research 8 143-157

Chaudhury RR and Sethi A (1970) Effects of an intra-uterine contraceptive device in the rat uterus on different days of pregnancy Journal of Reproduction and Fertility 22 33-40

Clark BF (1971) The effects of oestrogen on uterine cell division and epithelial morphology in spayed, adrenalectomized rats Journal of Endocrinology 50 $527-528$

Cullinan K and Koos RD (1991) Expression of basic fibroblast growth factor (BFGF), vascular endothelial growth factor (VEGF), and keratinocyte growth factor (KGF) in the rat uterus - stimulation by estrogen Biology of Reproduction 44 (Supplement 1), 186

Danova M, Riccardi A and Mazzini G (1990) Cell cycle-related proteins and flow cytometry Haematologica 75 252-264

Enders AC and Schlafke S (1967) A morphological analysis of the early implantation stages in the rat American Joumal of Anatomy 120 185-226

Engerman RL, Pfaffenbach D and Davis MD (1967) Cell turnover of capillaries Laboratory Investigation 17 738-743

Fairman MP (1990) DNA polymerase $\delta / P C N A$; actions and interactions Joumal of Cell Science 95 1-4

Finn CA and Martin L (1967) Patterns of cell division in the mouse uterus during early pregnancy Joumal of Endocrinology 39 593-597

Finn CA and Porter DG (1975) Morphological changes in the endometrium during the ovarian cycle. In The Uterus, pp 27-41. Elek Science, London

Folkman J (1985) Angiogenesis and its inhibitors. In Important Advances in Oncology, pp 42-62 Eds VT DeVita, S Hellman and SA Rosenberg. JB Lippincott, Philadelphia

Folkman J, Watson K, Ingber D and Hanahan D (1989) Induction of angiogenesis during the transition from hyperplasia to neoplasia Nature 339 58-61

Forcelledo ML, Vera R and Croxatto HB (1981) Ovum transport in pregnant, pseudopregnant, and cyclic rats and its relationship to estradiol and progesterone blood vessels Biology of Reproduction 24 760-765

Gaede SD, Sholley MM and Quattropani SL (1985) Endothelial mitosis during the initial stages of corpus luteum neovascularization in the cycling adult rat American Journal of Anatomy 172 173-180
Gole GA, Gannon BJ and Goodger AM (1982) Oxygen induced retinopathy: the kitten model re-examined Australian Joumal of Ophthalmology 10 223-232

Hall PA, Levison DA, Woods AL, Yu CC, Kellock DB, Watkins JA, Barnes DM, Gillett CE, Camplejohns R, Dover R, Waseem NH and Lane DP (1990) Proliferating cell nuclear antigen (PCNA) immunolocalization in paraffin sections: an index of cell proliferation with evidence of deregulated expression in some neoplasms Journal of Pathology 162 285-294

Hansen-Smith FM, Watson L, Lu DY and Goldstein I (1988) Griffonia simplicifolia I: fluorescent tracer for microcirculatory vessels in nonperfused thin muscles and sectioned muscle Microvascular Research 36 199-215

Johannisson E (1986) Effects of oestradiol and progesterone on the synthesis of DNA and the anti-haemophilic Factor VIII in human endometrial endothelial cells in vitro: a pilot study Human Reproduction $1207-212$

Krehbiel RH (1937) Cytological studies of the decidual reaction in the rat during early pregnancy and in the production of deciduomata Physiological Zoology 10 212-234

Laitinen L (1987) Griffonia simplicifolia lectins bind specifically to endothelial cells and some endothelial cells in mouse tissues Histochemical Journal 19 225-234

Martin L and Finn CA (1968) Hormonal regulation of cell division in epithelial and connective tissues of the mouse uterus journal of Endocrinology $\mathbf{4 1}$ 363-371

Martin L, Finn CA and Trinder G (1973) Hypertrophy and hyperplasia in the mouse uterus after oestrogen treatment: an autoradiographic study journal of Endocrinology 56 133-144

Messier B and Leblond CP (1960) Cell proliferation and migration as revealed by radioautography after injection of thymidine- $\mathrm{H}^{3}$ into male rats and mice American Journal of Anatomy 106 247-285

Paweletz N and Knierim M (1989) Tumor-related angiogenesis Critical Reviews in Oncology/Haematology 9 197-242

Presta M and Rifkin DB (1988) New aspects of blood vessel growth: tumor and tissue-derived angiogenesis factors Haemostasis 18 6-17

Ramsey EM (1977) Vascular anatomy. In Biology of the Uterus, pp 59-76 Ed. RM Wynn. Plenum Press, New York and London

Reynolds LP, Killilea SD and Redmer DA (1992) Angiogenesis in the female reproductive system FASEB Joumal 6 886-892

Rogers PAW, Macpherson AM and Beaton L (1992) Reduction in endometrial neutrophils in proximity to implanting rat blastocysts Journal of Reproduction and Fertility 96 283-288

Sholley MM and Cotran RS (1976) Endothelial DNA synthesis in the microvasculature of rat skin during the hair growth cycle American Journal of Anatomy 147 243-254

Tannock IF and Hayashi S (1972) The proliferation of capillary endothelial cells Cancer Research 32 77-82

Taylor CM, McLaughlin B, Weiss JB and Maroudas NG (1992) Concentrations of endothelial cell stimulating angiogenesis factor, a major component of human uterine angiogenesis factor, in human and bovine embryonic tissues and decidua Journal of Reproduction and Fertility 94 445-449

Welsh AO and Enders AC (1991) Chorioallantoic placenta formation in the rat: II. Angiogenesis and maternal blood circulation in the mesometrial region of the implantation chamber prior to placenta formation American Joumal of Anatomy 192 347-365

Wijsman JH, Van Dierendonck JH, Keijzer R, Van de Velde CJH and Cornelisse CJ (1992) Immunoreactivity of proliferating cell nuclear antigen compared with bromodeoxyuridine incorporation in normal and neoplastic rat tissue Journal of Pathology 168 75-83

Zetter BR (1988) Angiogenesis. State of the art Chest 93 (Supplement), 159S-166S 